ISSN 2073-4441

www.mdpi.com/journal/water

Article

\title{
Improving Water Use in Fodder Production
}

Vanessa Mendoza-Grimón ${ }^{1, *}$, José Manuel Hernández-Moreno ${ }^{2}$ and María del Pino Palacios-Díaz ${ }^{1}$

1 Departamento de Patología Animal, Producción Animal y Ciencia y Tecnología de los Alimentos, Grupo investigación GEOVOL, Universidad de Las Palmas de Gran Canaria, Las Palmas de Gran Canaria 35000, Spain; E-Mail: mp.palaciosdiaz@ulpgc.es

2 Departamento de Biología Animal, Edafología y Geología, Universidad de La Laguna, San Cristóbal de La Laguna 38071, Spain; E-Mail: jhmoreno@ull.es

* Author to whom correspondence should be addressed; E-Mail: v.mendozagrimon@ulpgc.es; Tel.: +34-928-454-353; Fax: +34-928-451-142.

Academic Editor: Miklas Scholz

Received: 13 April 2015 / Accepted: 21 May 2015 / Published: 27 May 2015

\begin{abstract}
Water deficit in semi-arid regions limits the future of the livestock sector. Also, its high price represents a percentage of the total cost of forage production. Non-conventional water resources applied by subsurface drip irrigation (SDI), in which the safe use lies in the management and not on the level of water treatment, would enhance the ruminant production sustainability. To obtain the optimal benefit, the transformation of water per kilogram of dry matter produced must have a high grade of effectiveness. Under this premise, a maralfalfa crop (Penissetum $s p$, hybridum) has been established with an SDI system and reclaimed water. Forage yield is analyzed with respect to a $40 \%$ irrigation reduction. This study shows that, with the use of these good irrigation management practices, it is possible to harvest an annual production of 90 to $72 \mathrm{t} \cdot \mathrm{ha}^{-1}$ in the warmer regions of the Canary Islands. This implies water consumption between 13,200 and $8100 \mathrm{~m}^{3} \cdot \mathrm{ha}^{-1}$. A water consumption of $21,000 \mathrm{~m}^{3} \cdot \mathrm{ha}^{-1}$ per year for the same production, at a ratio of $230 \mathrm{~L} \cdot \mathrm{t}^{-1}$, can be estimated for the rest of the Canary Islands coastal regions. The use of the water management described in this paper can be profitable in the Canary Islands for fodder production.
\end{abstract}

Keywords: water consumption coefficient; maralfalfa; subsurface drip irrigation; reclaimed water; water use efficiency (WUE) 


\section{Introduction}

"White" water or the efficient use thereof is defined as biomass production per square meter of water consumed, including both "green" water (effective rainfall) and "blue" (surface and groundwater) in the case of irrigated areas. The production of livestock feed consumes large amounts of white water, so a new concept appears: "livestock water productivity" [1]. Water scarcity has limited the livestock development in semiarid regions, as high price of water has an elevated percentage of the total cost of forage production. On the other hand, this sector is unable to compete with other sectors for the use of blue water. In this sense, water management is essential, especially if using non-conventional water resources (such as reclaimed water) as origin of irrigation water in fodder production. Moreover, using these resources, much abandoned land could be recovered by reducing the environmental impact of erosion. In current Spanish legislation [2], reclaimed water quality requirements for fodder irrigation (quality 2.2) are lower than the ones required for other uses. However, this legislation does not take into account the water management used in the field, for example: some irrigation types are not considered, and dosage and agro-environmental conditions are neglected. The soil could act as advanced water treatment system, allowing lower water quality in fodder irrigation, thereby avoiding the health problems. In fact, an FAO study concluded that rather than focusing only on the quality of wastewater, it would be better to ass and manage the risks of using reclaimed water to achieve the same goal of health guarantee [3]. This study determined that subsurface drip irrigation (SDI) allows the use of effluent with a lower level of treatment to reaching the same health security. In this sense, Palacios [4] concluded that SDI optimizes water by preventing water loss and providing greater health guarantee. Jensen [5] linked the crop yields with water use. This author cited several factors that affect the water efficiency, such as climatic factors, water efficient application and the crop physiology. Márquez [6] demonstrated that maralfalfa grass (Pennisetum $s p$ ) is an alternative to increase forage availability for livestock due to its high dry matter productivity and nutritive values, provided once the minimum requirements for this species are satisfied. However, few studies [7] mentioned the water needs of this fodder, which often conduces to misuse of this resource. The aim of this study was to optimize the reclaimed urban water use in the maralfalfa crop in the Canary Islands agro-climatic conditions.

\section{Materials and Methods}

\subsection{Experimental Plot}

During 2014, the Maralfalfa grass (Pennisetum $s p$ ) experiment was conducted in a field of $272 \mathrm{~m}^{2}$ situated in Granja Agrícola Experimental del Cabildo de Gran Canaria. An automatic weather station, used to calculate reference Penman-Monteith Evapotranspiration (ETo), was already set in the field. During the study, three maralfalfa harvests were obtained: first productive period, from February to May (harvest on 22 May), the second: May to July (17 July) and the third: July to September (17 September). Rainfall was low: 3.7, 3.8 and $7.4 \mathrm{~mm}$ respectively, compared with the average of 83.37 during the period from February to September (191.6 of annual value average for the 14 last years, which is the period with available information). Mean of minimum temperatures (Tm) was $17^{\circ} \mathrm{C}$ and mean of maximum temperatures (TM) was $25^{\circ} \mathrm{C}$. Mean temperature (Tmed) is presented in 
Figure 1. During the previous 14 years, the average values of the minimum and maximum temperatures were $11{ }^{\circ} \mathrm{C}$ and $31^{\circ} \mathrm{C}$, respectively. The field is classified as Anthrosol [8] or Torriarent [9].

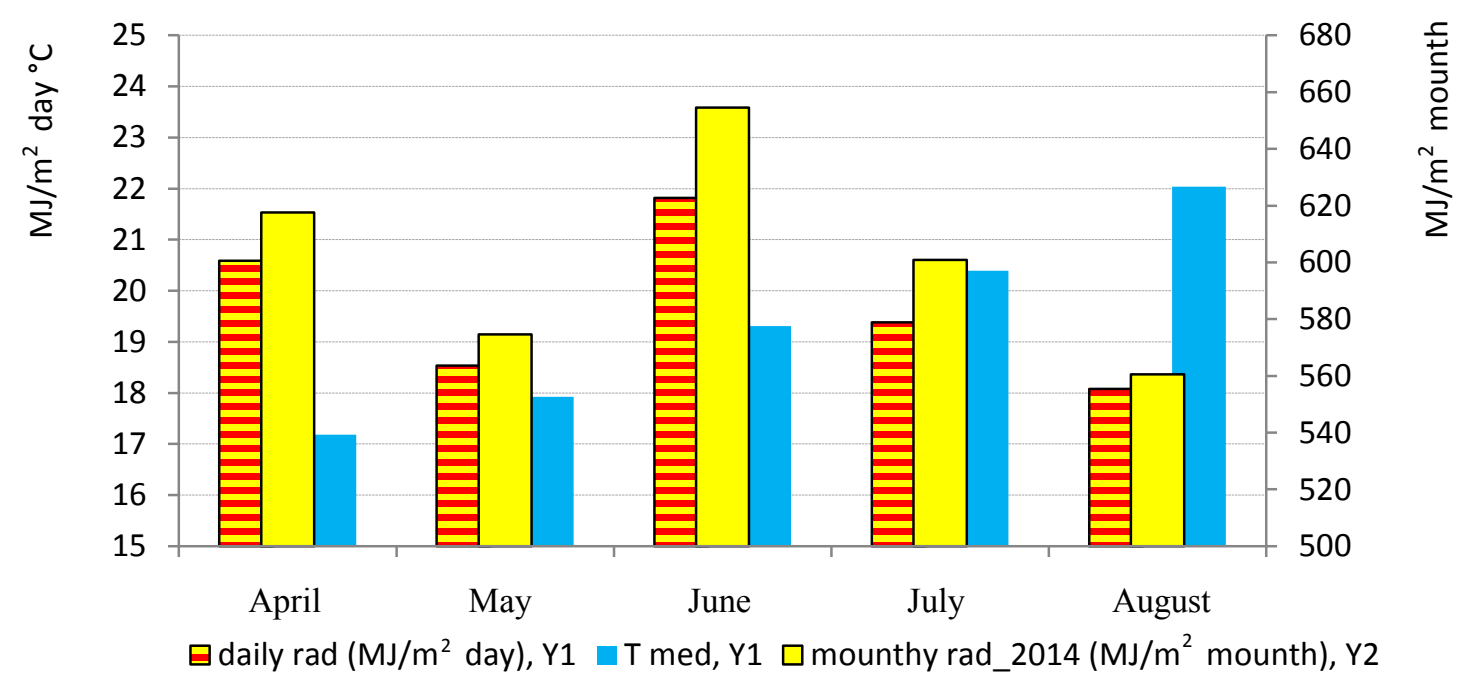

Figure 1. Meteorological data during the experimental period: daily radiation (daily rad) expressed in $\mathrm{MJ} \cdot \mathrm{m}^{-2} \cdot \mathrm{day}^{-1}$, mean temperature, expressed in day ${ }^{\circ} \mathrm{C}$ (Tmed) and monthly radiation (monthly rad) in $\mathrm{MJ} \cdot \mathrm{m}^{-2} \cdot \mathrm{month}^{-1}$.

An experimental plot of $272 \mathrm{~m}^{2}$ was divided in two blocks with two treatments in each (T1 and T2). Each treatment consists of five lines of approximately $21 \mathrm{~m}$ long, coinciding with the irrigation lines. These lines are spaced at $0.75 \mathrm{~m}$. Therefore, both $\mathrm{T} 1(100 \%$ of dose) and T2 (60\% of dose), are irrigated in each block.

During the third harvest, a fertilization compatible with organic farming management was applied (Lignoser, $\mathrm{n}^{\circ} \mathrm{CE} / 19287$ ), at a rate of $1.1 \mathrm{~g} / \mathrm{m}^{2} \mathrm{~N}$. Fertilizer also provides fulvic acid, $\mathrm{K}$ and trace elements.

\subsection{Soil Analysis}

Sample soils were taken from the first $0.2 \mathrm{~m}$, coinciding with the transplant and harvest days. Table 1 shows the results in each block. Organic carbon (OC, \%) and nitrogen (N, \%) were determined by dry combustion with a LECO CNS 2000 analyzer. Soluble salts were estimated by the electrical conductivity $\mathrm{EC}_{1: 5}$ (soil:water ratio; $\mathrm{dS} / \mathrm{m}$ ). Available nitrate was determined by extraction of soil, also at 1:5 ratio, with $0.01 \mathrm{M}$ calcium chloride, and analyzed by ionic chromatography. Available soil $\mathrm{P}(\mathrm{mg} / \mathrm{kg})$ was determined by sodium bicarbonate extraction, according to Olsen method [10]. Exchangeable cations ( $\mathrm{K}, \mathrm{Ca}, \mathrm{Mg}$, and $\mathrm{Na}$, meq $100 \mathrm{~g}^{-1}$; $\mathrm{B}, \mathrm{Fe}, \mathrm{Cu}, \mathrm{Mn}$ and $\mathrm{Zn}, \mathrm{mg} \cdot \mathrm{kg}^{-1}$ ) were extracted with buffered $1 \mathrm{M}$ ammonium acetate at $\mathrm{pH} 7$, and were analyzed by ICP. 
Table 1. Determination of organic matter (OM, expressed in \%), total nitrogen ( $\mathrm{N}$ tot, expressed in \%), electrical conductivity 1:5 (EC, dS/m), nitrate (expressed in $\mathrm{mg} \cdot \mathrm{kg}^{-1}$, available phosphorus ( $\mathrm{P}$, expressed in $\mathrm{mg} \cdot \mathrm{kg}^{-1}$ ), extracted cations (expressed as me $100 \mathrm{~g}^{-1}$ ): potassium $(\mathrm{K})$, calcium $(\mathrm{Ca})$, magnesium $(\mathrm{Mg})$, sodium $(\mathrm{Na})$, and the rest of analyzed nutrients (expressed in $\left.\mathrm{mg} \cdot \mathrm{kg}^{-1}\right)$ : boron $(\mathrm{B})$, copper $(\mathrm{Cu})$, iron $(\mathrm{Fe})$, manganese $(\mathrm{Mn})$ and zinc $(\mathrm{Zn})$, for T1 and T2, expressed by mean and standard deviation.

\begin{tabular}{|c|c|c|c|c|c|c|c|c|c|c|c|c|c|c|c|c|c|c|}
\hline \multirow{2}{*}{ Transplant } & \multirow{2}{*}{\multicolumn{2}{|c|}{$\mathbf{T 1} / \mathbf{T} 2$}} & pH & CE 1:5 & OM & $\mathbf{C} / \mathbf{N}$ & $\mathrm{N}$ tot & Nitrate & $\mathbf{P}$ & $\mathbf{K}$ & $\mathbf{C a}$ & Mg & $\mathbf{N a}$ & B & $\mathrm{Cu}$ & $\mathbf{F e}$ & Mn & Zn \\
\hline & & & 8.1 & 1.23 & 6.61 & 10.55 & 0.36 & 498 & 151.5 & 9.58 & 24.82 & 8.85 & 5.8 & 6.63 & -- & -- & -- & -- \\
\hline \multirow{4}{*}{ May } & \multirow{2}{*}{$\mathrm{T} 1$} & Mean & $8.6^{b}$ & 0.7 & $3.0^{\mathrm{a}}$ & 8.4 & 0.21 & $171^{\mathrm{a}}$ & $123^{a}$ & $8.0^{\mathrm{a}}$ & 18.8 & $8.9^{\mathrm{c}}$ & $4.01^{\mathrm{a}}$ & 6.6 & $1.6^{\mathrm{b}}$ & $4.5^{\mathrm{a}}$ & $12.9^{\mathrm{a}}$ & $4.2^{b}$ \\
\hline & & Std. & 0.07 & 0.28 & 0.12 & 0.14 & 0.01 & 46.7 & 33.9 & 4.31 & 0.64 & 0.35 & 1.41 & 0.00 & 0.00 & 0.57 & 0.00 & 0.38 \\
\hline & \multirow{2}{*}{$\mathrm{T} 2$} & Mean & $8.6^{b}$ & 0.5 & $2.5^{\mathrm{a}}$ & 8.5 & 0.17 & $152^{\mathrm{a}}$ & $75^{a}$ & $5.5^{\mathrm{a}}$ & 20.5 & $9.4^{\mathrm{c}}$ & $4.10^{\mathrm{a}}$ & 5.7 & $1.8^{\mathrm{b}}$ & $4.9^{\mathrm{a}}$ & $13.2^{\mathrm{a}}$ & $4.1^{b}$ \\
\hline & & Std. & 0.0 & 0.08 & 0.46 & 0.92 & 0.01 & 28.3 & 33.2 & 2.12 & 1.56 & 0.42 & 0.14 & 0.57 & 0.07 & 0.35 & 1.7 & 0.00 \\
\hline \multirow{4}{*}{ July } & \multirow{2}{*}{$\mathrm{T} 1$} & Mean & $8.5^{\mathrm{a}}$ & 1.1 & $3.2^{\mathrm{a}}$ & 8.6 & 0.22 & $295^{a}$ & $174^{a}$ & $9.8^{\mathrm{a}}$ & 26.00 & $6.00^{\mathrm{a}}$ & $6.90^{b}$ & 8.1 & $1.0^{\mathrm{a}}$ & $2.7^{\mathrm{a}}$ & $11.1^{\mathrm{a}}$ & $2.5^{\mathrm{a}}$ \\
\hline & & Std. & 0.0 & 0.29 & 0.32 & 0.0 & 0.02 & 135.1 & 50.2 & 4.24 & 4.03 & 0.64 & 0.49 & 1.27 & 0.03 & 0.14 & 1.06 & 2.07 \\
\hline & \multirow{2}{*}{$\mathrm{T} 2$} & Mean & $8.4^{\mathrm{a}}$ & 0.6 & $2.7^{\mathrm{a}}$ & 8.2 & 0.19 & $206^{\mathrm{a}}$ & $86^{a}$ & $5.6^{\mathrm{a}}$ & 28.4 & $7.00^{b}$ & $5.00^{b}$ & 6.7 & $1.2^{\mathrm{a}}$ & $3.4^{\mathrm{a}}$ & $13.4^{\mathrm{a}}$ & $2.5^{\mathrm{a}}$ \\
\hline & & Std. & 0.0 & 0.09 & 0.28 & 0.28 & 0.03 & 91.9 & 38.9 & 1.63 & 2.62 & 0.21 & 0.35 & 1.27 & 0.21 & 1.06 & 1.41 & 0.78 \\
\hline \multirow{4}{*}{ September } & \multirow{2}{*}{$\mathrm{T} 1$} & Mean & $8.5^{\mathrm{a}}$ & 1.2 & $3.3^{b}$ & 8.8 & 0.22 & $250^{\mathrm{a}}$ & $124^{\mathrm{a}}$ & 10.4 & 23.8 & $8.2^{c}$ & $6.90^{b}$ & 7.3 & $2.6^{\mathrm{c}}$ & $7.7^{b}$ & $26.6^{\mathrm{b}}$ & $7.2^{\circ}$ \\
\hline & & Std. & 0.0 & 0.58 & 0.05 & 0.14 & 0.01 & 101.1 & 50.9 & 5.52 & 14.71 & 3.32 & 1.34 & 1.13 & 0.57 & 1.63 & 1.7 & 1.27 \\
\hline & \multirow{2}{*}{$\mathrm{T} 2$} & Mean & $8.5^{\mathrm{a}}$ & 1.2 & $2.9^{\mathrm{a}}$ & 8.8 & 0.19 & $146^{\mathrm{a}}$ & $87^{a}$ & $5.9^{\mathrm{a}}$ & 29.2 & $8.8^{\mathrm{c}}$ & $5.60^{b}$ & 6.9 & $2.3^{\mathrm{c}}$ & $6.7^{\mathrm{b}}$ & $32.1^{\mathrm{b}}$ & $7.7^{\circ}$ \\
\hline & & Std. & 0.7 & 0.65 & 0.2 & 0.07 & 0.01 & 45.3 & 49.5 & 2.12 & 18.1 & 4.31 & 0.35 & 0.78 & 0.28 & 1.34 & 2.4 & 1.38 \\
\hline
\end{tabular}




\subsection{Forage Characterization}

Fresh matter production was weighed in field in each harvest for the different lines. Composite samples of the different treatments were taken to determine the percentage of dry matter (DM), macro- and microelements (Table 2). Dry matter (DM) was determined by drying in an oven at $60{ }^{\circ} \mathrm{C}$ to constant weight. Plant samples were subjected to microwave digestion with nitric acid. The following elements were analyzed by inductively coupled plasma optical emission spectrometry (ICP-OES): P, K, Ca, Mg, Na (expressed in \%), B, Cu, Fe, Mn and $\mathrm{Zn}$ (expressed in mg/kg). Nitrogen was determined by dry combustion in an LECO CNS 2000.

\subsection{Irrigation System}

Ground water was applied by subsurface drip irrigation (SDI) system with integral drippers: pressure-compensating at range 1.5-4.0 bar, anti-Siphon and high anti-drain mechanism (Techline mod) spaced $0.5 \mathrm{~m}$ with delivery rates at $2.3 \mathrm{~L} \cdot \mathrm{h}^{-1}$, being an abnormal low flow for drip irrigation. The lateral lines were spaced to $0.75 \mathrm{~m}$. Irrigation was provided daily two times a day during $20 \mathrm{~min}$ and $12 \mathrm{~min}$ ( $\mathrm{T} 1$ and $\mathrm{T} 2$ respectively) on each irrigation event. The weather station information was used for irrigation in this experiment. Each treatment has a flow meter, read weekly. Table 3 shows water consumption $\left(\mathrm{L} \cdot \mathrm{m}^{-2}\right)$ for each harvest.

\subsection{Statistical Analysis}

Analyses of variance (ANOVA) were carried out using statistical Packaged SPSS (version 22) by the Generalized Linear Model. The model includes soil parameters, leaf nutrients and yield (expressed as $\left.\mathrm{kg} \cdot \mathrm{DM} \cdot \mathrm{m}^{-2}\right)$ from each harvest, the irrigation doses $(100 \%$ and $60 \%)$ and their interactions. Mean separation was tested using the least significant difference (LSD), considering $p=0.05$

\section{Results and Discussion}

Figure 1 shows the climatic data during the experimental periods. As observed, there are a progressive increase in the Tmed and a relatively low radiation values at the time of study (higher radiation in June than in July and August).

The soil nutrients, present in Table 1, show the high content of OM while Ntot content is stable (it does not present significant differences), which is consistent with the low relation $\mathrm{C} / \mathrm{N}$. Although not significant, there is a salinization trend on the surface horizon, compatible with water and irrigation system management. Although it does not show significant differences, nitrate content decreased slightly over time, but it remained at acceptable levels (between 321 and $114 \mathrm{mg} \cdot \mathrm{kg}^{-1}$ for September) to ensure an adequate forage growth. However, $\mathrm{N}$ deficiency symptoms in plant were observed, coinciding with low values of leaf $\mathrm{N}$ content (Figure 2, T1), so fertilizer was applied. These $\mathrm{N}$ contents correspond to values of crude protein (CP) between 5.3\% and 7.7\%, lower values than would be expected for harvesting at 60 days $(8.8 \%,[11])$. This apparent contradiction between adequate nitrate values in soil and low $\mathrm{N}$ leaf contents can be explained because the soil sampling was done from top soil to $0.2 \mathrm{~m}$ and, due to the localization of the irrigation system (buried), the root system is not able to absorb the nitrate ascended by capillary rise. Trace elements are increased for the third cut, which seems to be influenced by the fertilizer used. 
Table 2. Determination of dry matter (DM, expressed in \%), nitrogen $(\mathrm{N})$, phosphorus $(\mathrm{P})$ potassium $(\mathrm{K})$, calcium $(\mathrm{Ca})$, magnesium $(\mathrm{Mg})$ and sodium $(\mathrm{Na})$, expressed in $\%$ and other elements (expressed in $\mathrm{mg} / \mathrm{kg})$ ) boron $(\mathrm{B})$, copper $(\mathrm{Cu})$, iron $(\mathrm{Fe})$, manganese $(\mathrm{Mn})$ and zinc $(\mathrm{Zn})$ for forage harvested at different dates and for each of the treatments, T1 and T2, expressed by mean and standard deviation.

\begin{tabular}{|c|c|c|c|c|c|c|c|c|c|c|c|c|c|c|}
\hline Transplant & & & DM & $\mathbf{N}$ & $\mathbf{P}$ & $\mathbf{K}$ & $\mathbf{C a}$ & Mg & $\mathbf{N a}$ & B & $\mathrm{Cu}$ & $\mathbf{F e}$ & Mn & Zn \\
\hline \multirow{4}{*}{ May } & \multirow{2}{*}{$\mathrm{T} 1$} & Mean & $9.42^{\mathrm{a}}$ & $0.86^{\mathrm{a}}$ & $0.31^{\mathrm{a}, \mathrm{b}}$ & $5.75^{c}$ & 0.17 & 0.11 & 0.07 & 11.50 & 5.50 & 64.00 & 36.50 & 23.00 \\
\hline & & std & 0.85 & 0.12 & 0.12 & 0.25 & 0.10 & 0.01 & 0.04 & 0.71 & 0.71 & 15.56 & 7.78 & 2.83 \\
\hline & \multirow{2}{*}{$\mathrm{T} 2$} & Mean & $9.70^{\mathrm{a}}$ & $1.23^{\mathrm{a}}$ & $0.22^{\mathrm{a}}$ & $5.46^{\mathrm{c}}$ & 0.20 & 0.14 & 0.07 & 9.50 & 6.00 & 77.50 & 48.00 & 26.50 \\
\hline & & std & 0.07 & 0.38 & 0.06 & 0.08 & 0.04 & 0.04 & 0.01 & 2.12 & 0.00 & 6.36 & 9.90 & 0.71 \\
\hline \multirow{2}{*}{ July } & \multirow{2}{*}{$\mathrm{T} 1$} & Mean & $9.56^{\mathrm{a}}$ & $0.9^{\mathrm{a}}$ & $0.36^{\mathrm{b}}$ & $5.13^{b}$ & 0.13 & 0.15 & 0.06 & 16.50 & 5.00 & 81.00 & 35.00 & 37.50 \\
\hline & & std & 0.00 & 0.24 & 0.04 & 0.08 & 0.03 & 0.01 & 0.02 & 0.71 & 0.00 & 32.53 & 4.24 & 9.19 \\
\hline \multirow{2}{*}{ July } & \multirow{2}{*}{$\mathrm{T} 2$} & Mean & $9.56^{\mathrm{a}}$ & $1.00^{\mathrm{a}}$ & $0.36^{\mathrm{b}}$ & $4.98^{b}$ & 0.12 & 0.16 & 0.05 & 17.00 & 5.00 & 71.50 & 34.00 & 36.00 \\
\hline & & std & 0.00 & 0.03 & 0.04 & 0.50 & 0.01 & 0.02 & 0.01 & 1.41 & 0.00 & 23.33 & 5.66 & 9.90 \\
\hline \multirow{4}{*}{ September } & \multirow{2}{*}{$\mathrm{T} 1$} & Mean & $21.26^{\mathrm{b}}$ & $0.85^{\mathrm{a}}$ & $0.34^{\mathrm{b}}$ & $4.97^{b}$ & 0.10 & 0.13 & 0.04 & 11.50 & 4.50 & 70.50 & 22.00 & 36.50 \\
\hline & & std & 0.96 & 0.21 & 0.04 & 0.35 & 0.01 & 0.03 & 0.01 & 0.71 & 0.71 & 12.02 & 4.24 & 2.12 \\
\hline & \multirow{2}{*}{$\mathrm{T} 2$} & Mean & $21.83^{b}$ & $1.04^{\mathrm{a}}$ & $0.25^{\mathrm{a}}$ & $3.84^{\mathrm{a}}$ & 0.13 & 0.14 & 0.04 & 14.00 & 4.00 & 75.00 & 28.00 & 29.50 \\
\hline & & std & 1.05 & 0.59 & 0.03 & 0.40 & 0.08 & 0.04 & 0.01 & 4.24 & 0.00 & 22.63 & 9.90 & 6.36 \\
\hline
\end{tabular}

Note: ${ }^{a, b, c}$ Different letters in superscript following values indicate statistical significance.

Table 3. Period of study (days); thermal integral (TI); radiation ( $\left.\mathrm{rad}, \mathrm{MJ} \cdot \mathrm{m}^{-2}\right)$, water consumption, $\mathrm{W}_{\mathrm{cons}},\left(\mathrm{L} \cdot \mathrm{m}^{-2}\right)$; accumulated $($ Ac) and mean evapotranspiration $\left(\mathrm{ETo}, \mathrm{L} \cdot \mathrm{m}^{-2}\right)$; water consumption/ETo $(\%)$; production $\left(\mathrm{kg} \cdot \mathrm{m}^{-2} \mathrm{DM}\right)$ and water consumption per $\mathrm{kg}$ of dry matter $(\mathrm{Water}$ consumption coefficient, $\mathrm{L}^{\mathrm{kg}} \mathrm{kg}^{-1} \mathrm{DM}$ ) produced for the different harvest periods and treatments, for $\mathrm{T} 1$ and $\mathrm{T} 2$ expressed by mean and standard deviation.

\begin{tabular}{|c|c|c|c|c|c|c|c|c|c|c|c|c|c|c|c|c|c|}
\hline \multirow{3}{*}{ Date } & \multirow{3}{*}{ Days } & \multirow{2}{*}{\multicolumn{2}{|c|}{ TI Period Rad Period }} & \multirow{2}{*}{\multicolumn{2}{|c|}{$\mathbf{W}_{\text {cons }}\left(\mathbf{L} / \mathbf{m}^{2}\right)$}} & \multirow{2}{*}{\multicolumn{2}{|c|}{$\operatorname{ETo}\left(\mathbf{L} / \mathbf{m}^{2}\right)$}} & \multirow{2}{*}{\multicolumn{2}{|c|}{$\mathbf{W}_{\text {cons }} / \operatorname{ETo}(\%)$}} & \multicolumn{4}{|c|}{ T1 } & \multicolumn{4}{|c|}{$\mathbf{T} 2$} \\
\hline & & & & & & & & & & \multicolumn{2}{|c|}{$\mathrm{kgDM} \cdot \mathrm{m}^{-2}$} & \multicolumn{2}{|c|}{$\mathbf{L} \cdot \mathbf{k g}^{-1} \mathbf{D M}$} & \multicolumn{2}{|c|}{$\operatorname{kgDM} \cdot \mathrm{m}^{-2}$} & \multicolumn{2}{|c|}{$\mathbf{L} \cdot \mathbf{k g}^{-1} \mathrm{DM}$} \\
\hline & & $\circ$ & $\mathbf{M J} / \mathbf{m}^{2}$ & T1 & $\mathbf{T 2}$ & Ac & Mean & T1 & T2 & Mean & Std & Mean & Std & Mean & Std & Mean & Std \\
\hline 22 May 2014 & 100 & 900 & 1862 & 287 & 243 & 333.1 & 3.3 & 86.2 & 73.0 & $0.40^{\mathrm{a}}$ & 0.02 & $712^{f}$ & 40.64 & $0.42^{\mathrm{a}}$ & 0.06 & $583^{\mathrm{e}}$ & 81.10 \\
\hline 17 July 2014 & 55 & 519 & 1097 & 203 & 127 & 211.4 & 3.8 & 96.0 & 60.1 & $0.40^{\mathrm{a}}$ & 0.03 & $516^{\mathrm{d}}$ & 41.41 & $0.36^{\mathrm{a}}$ & 0.04 & $355^{\mathrm{c}}$ & 42.50 \\
\hline 17 September 2014 & 60 & 706 & 1183 & 197 & 118 & 224.3 & 3.6 & 87.8 & 52.6 & $1.08^{\mathrm{c}}$ & 0.04 & $182^{b}$ & 6.98 & $0.88^{b}$ & 0.05 & $134^{\mathrm{a}}$ & 7.58 \\
\hline
\end{tabular}

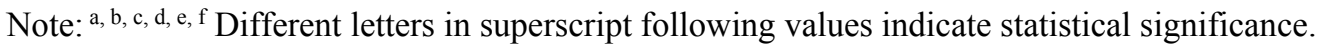




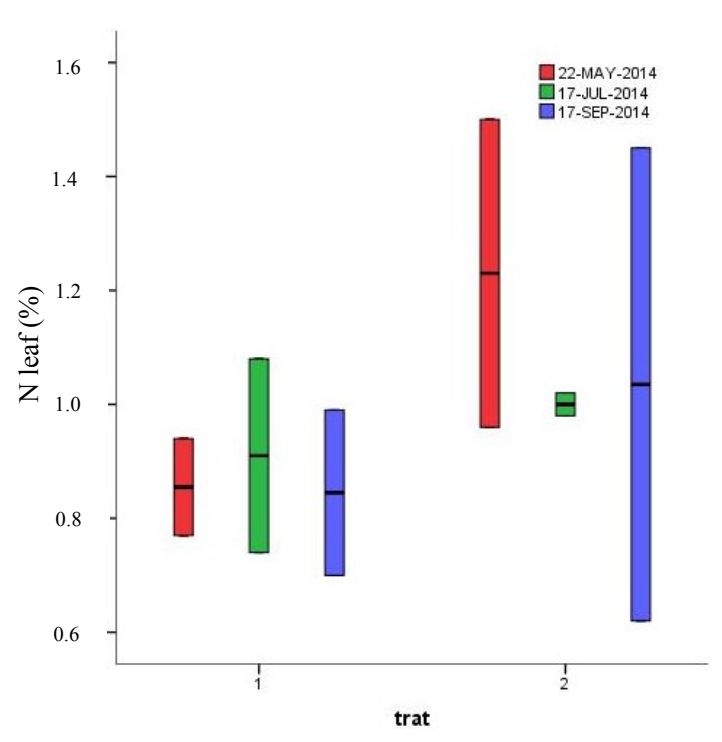

Figure 2. Nitrogen leaf content, expressed in \%, for both treatments (trat 1: 100\% and trat 2: 60\% of the dose) for three harvests (represented by the date of cutting).

Nutrient contents in leaves (Table 2) remain relatively stable, although decreasing slightly over time. As observed in Figure 2, reduction dose treatment (T2) shows higher N contents in leaves, although these differences were not significant. Adequate $\mathrm{P}$ contents were measured (between $0.2 \%$ and $0.4 \%$ ). No relationship was found between increased contents in soil, after fertilizer application, and leaf contents.

A great increase in DM harvested in the third period (September 2014) was obtained (Figure 3a), yielding significantly more than the other two ones. This production could be the result from the higher temperatures in this period (see T med in Figure 1). To explain this result, the thermal integral (TI) for the experimental periods was calculated (Table 3), as a sum of daily temperatures above $10^{\circ} \mathrm{C}$ (zero vegetation for this forage, [12]). The TI for the first period was very high, because it corresponded to the establishment phase (100 days). Although periods 2 and 3 were similar in terms of days, the lower TI for the second period vs. the third (75\% versus $100 \%)$, showed a significantly lower yield than obtained by the third period.

Table 3 shows the water consumption $\left(\mathrm{L} \cdot \mathrm{m}^{-2}\right)$ and yield $\left(\mathrm{kg} \cdot \mathrm{DM} \cdot \mathrm{m}^{-2}\right)$ for the different periods. Water consumption divided by ETo, shows that the ratio of consumption average were $0.9,1$ and 0.9 for the three periods in $\mathrm{T} 1$, whereas for $\mathrm{T} 2$ were $0.7,0.6$ and 0.5 respectively. Therefore, water consumption coefficients are slightly higher for $\mathrm{T} 1$ and slightly lower for $\mathrm{T} 2$ to those obtained by Murillo Solano [7], since these authors quote to ET $3 \mathrm{~L} \cdot \mathrm{m}^{-2}$ per day, and Kc from 1 to 0.7. In fact, as shown in Figure 3b, water consumption divided by dry matter produced (water consumption coefficient) demonstrated significant differences between treatment and dates since the second harvest (once the plant was established). Higher values were obtained in both dates for controlling dose (T1), (516 and $\left.182 \mathrm{~L} \cdot \mathrm{kg}^{-1} \cdot \mathrm{DM}\right)$ versus T2 (355 and $\left.134 \mathrm{~L}^{\circ} \mathrm{kg}^{-1} \mathrm{DM}\right)$. The significant differences between yield obtained in T1 and T2 in September (Figure 3a) were high, demonstrating that water, although used very efficiently in both treatments (Figure 3b), was the limiting factor for this period. However, in the establishment period (May), no differences were found. Depending on the water and fodder price, the farmer could or could not use a reduction in the irrigation dose. 


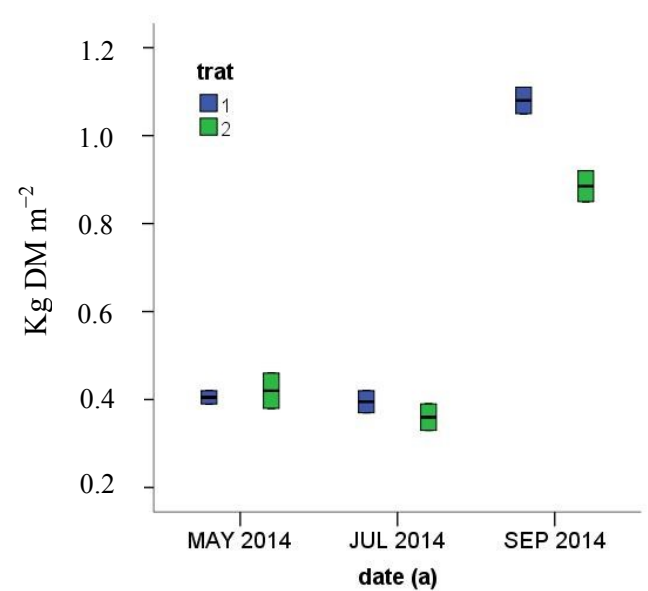

(a)

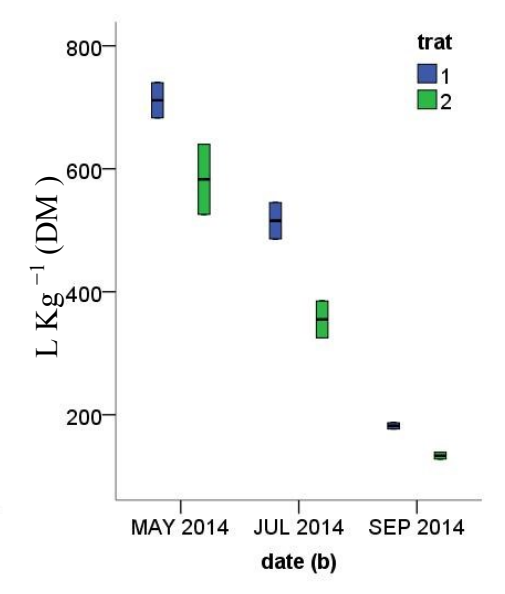

(b)

Figure 3. (a) Yield $\left(\mathrm{kg} \cdot \mathrm{DM} \cdot \mathrm{m}^{-2}\right)$ and (b) water consumption per dry matter produced, water consumption coefficient $\left(\mathrm{L} \cdot \mathrm{kg}^{-1} \mathrm{DM}\right)$ for both treatments (trat 1: $100 \%$ and trat 2: $60 \%$ of the dose) and harvests.

Water consumption coefficients obtained for the third cut, once the plant is established and with very supportive temperatures for this crop, are exceptionally favorable (Figure 4 left). This figure shows that in September, the best yields were obtained, although the water applied was limited. This was possible because the water consumption coefficient is extremely favorable (182 and $134 \mathrm{~L} \cdot \mathrm{kg}^{-1} \mathrm{DM}$, respectively for T1 and T2 treatments, Table 3). This fact contributes to the high water use efficiency (WUE), which was calculated using the ratio of dry mass per area ( $\mathrm{kg} \cdot \mathrm{ha})$ and the amount of water consumed (mm), whose values are shown in Figure 4 right), values above those mentioned for a C3 grass, [13]. This high WUE can be explained by the subsurface drip irrigation system (practically all the water supplied is absorbed by the plant), water management (low dose twice daily) and plant physiology (C4 metabolism).

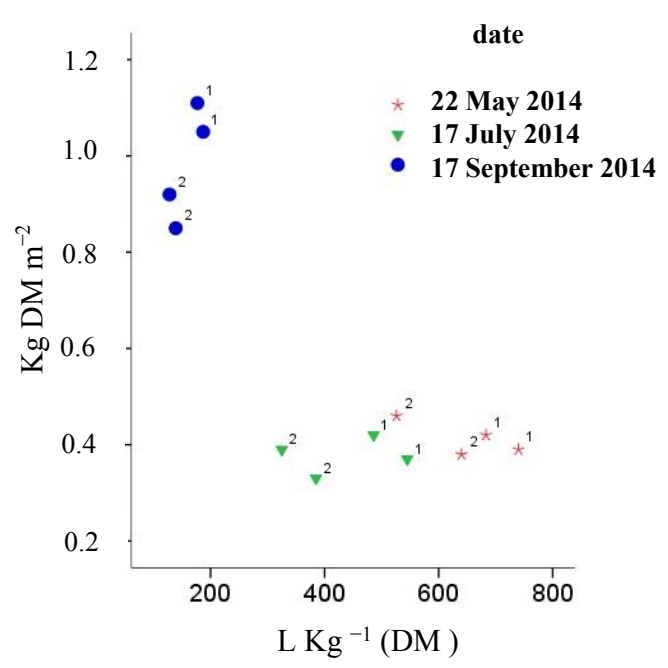

(a)

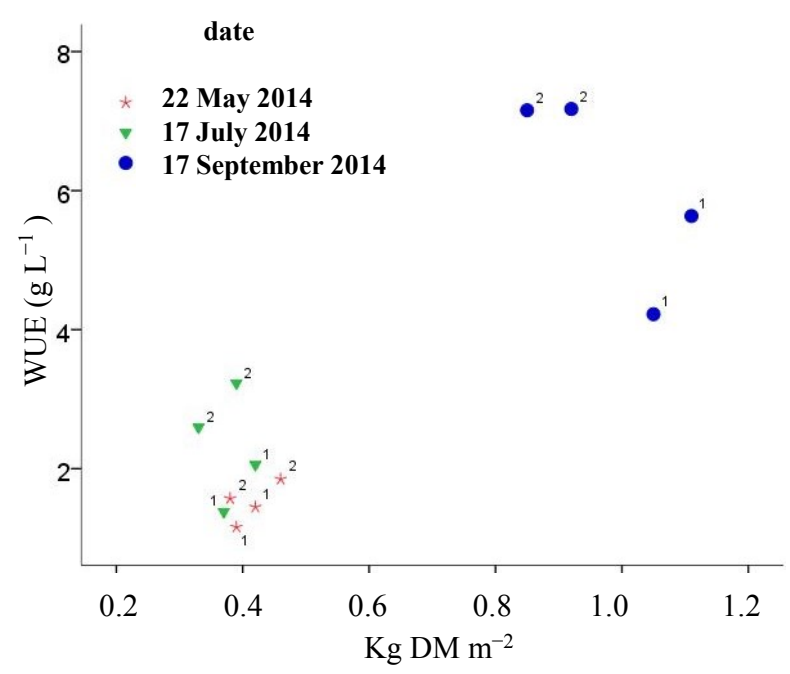

(b)

Figure 4. (a) Yield $\left(\mathrm{kg} \cdot \mathrm{m}^{-2} \mathrm{DM}\right)$ and water consumption coefficient $\left(\mathrm{L}^{\mathrm{kg}} \mathrm{kg}^{-1} \mathrm{MS}\right)$ for both treatments $(100 \%$ and $60 \%$ of the dose) and harvest; and (b) relationship between water use efficiency (WUE, in $\mathrm{g} \cdot \mathrm{L}^{-1}$ ) and crop yield $\left(\mathrm{kg} \cdot \mathrm{m}^{-2} \mathrm{DM}\right)$ obtained for the harvests and treatments (1 and 2). 
Under these conditions, maralfalfa production is very efficient in water use and can be estimated that, for a production of 72 to $90 \mathrm{t}$ of hay $\cdot \mathrm{ha}^{-1}$ respectively (with or without a reduction in irrigation) the amount of water would be $13,200 \mathrm{~m}^{3} \cdot \mathrm{ha}^{-1}$ or $9600 \mathrm{~m}^{3} \cdot \mathrm{ha}^{-1}$.

\section{Conclusions}

Fodder production is possible in warm areas of the Canary Islands with a good water management, providing the appropriate technology, despite the high price of water. In this sense the farmers need to use a high efficiency irrigation system, a crop that take advantage of the favorable conditions of temperature and radiation and no-conventional water resources whose safety use is filed in the water management and not in the treatment level.

When subsurface drip irrigation systems are used, the soil profile explored by roots is modified. This factor must be taken into account when sampling the soil and providing nutrients, especially when the fodder demands high quantities of these elements.

For the warmer regions of the Canaries, whose average monthly temperatures are at or above $22{ }^{\circ} \mathrm{C}$, our studies allow us to estimate an accumulated production (annual) of 90 or $72 \mathrm{t} \cdot \mathrm{ha}^{-1}$. hay (control or dose reduction of $40 \%$ ), with water applied between 13,200 and $8100 \mathrm{~m}^{3} \cdot \mathrm{ha}^{-1}$. For other coastal regions, where this species can be cultivated, but in which the use of water is not as effective (as occurred in July), the amount of water needed to obtain the same yield can be estimated in about $21,000 \mathrm{~m}^{3} \cdot \mathrm{ha}^{-1}$.

\section{Acknowledgments}

This work was supported by Ministry of Economy and Finance. Subprogram Basic Research Projects (CGL2012-39520-C03-03) and Research Canary Agency, of the Gobierno de Canarias (SolSubC200801000012). We also appreciate the cooperation of the Phytopathological Laboratory and Agri-Food and Agricultural Experimental Farm of Cabildo de Gran Canaria.

\section{Author Contributions}

Mendoza-Grimón and Palacios-Diaz-had the original idea for the study and, with all co-authors carried out the design. Mendoza-Grimón and Palacios-Diaz were responsible for recruitment and follow-up of study participants. Mendoza-Grimón, Palacios-Diaz and Hernández-Moreno were responsible for data cleaning and carried out the analyses. Mendoza-Grimón and Palacios-Diaz drafted the manuscript, which was revised by all authors. All authors read and approved the final manuscript.

\section{Conflicts of Interest}

The authors declare no conflict of interest.

\section{References}

1. Peden, D.; Tadesse, G.; Misra, A.K. Water and livestock for human development. In Water for Food, Water for Life: A Comprehensive Assessment of Water Management in Agriculture; 
Molden, D., Ed.; Earthscan: London, UK; International Water Management Institute: Colombo, Sri Lanka, 2007; pp. 485-514.

2. Real Decreto 1620/2007, de 7 de Diciembre, Por el Que se Establece el Régimen Jurídico de la Reutilización de las Aguas Depuradas. Available online: http://www.boe.es/diario_boe/ txt.php?id=BOE-A-2007-21092 (accessed on 25 May 2015).

3. Winpenny, J.; Heinz, I.; Koo-Oshima, S. Reutilización del Agua en Agricultura: Beneficios Para Todos? FAO Informe sobre Temas hídricos: Rome, Italy, 2013; p. 35.

4. Palacios-Díaz, M.P.; Mendoza-Grimón, V.; Fernández-Vera, J.R.; Rodríguez-Rodríguez, F.; Tejedor-Junco, M.T.; Hernández-Moreno, J.M. Subsurface drip irrigation and reclaimed water quality effects on phosphorus and salinity distribution and forage production. Agric. Water Manag. 2009, 96, 1659-1666.

5. Jensen, M.E. Water consumption by agricultural plants. In Water Deficits and Plant Growth; Kozlowski, T.T., Ed.; Academic Press: New York, NY, USA, 1968; pp. 1-22.

6. Márquez, F.; Sánchez, J.; Urbano, D.; Dávila, C. Evaluación de la frecuencia de corte y tipos de fertilización sobre tres genotipos de pasto elefante (Pennisetum purpureum). 1. Rendimiento y contenido de proteína. Zootec. Trop. 2007, 25, 253-259. (In Spanish)

7. Murillo Solano, J.; Barros Henríquez, J.A.; Roncallo Fandiño, B.; Arrieta Pico, G. Requerimientos hídricos de cuatro gramíneas de corte para uso eficiente del agua en el Caribe seco colombiano. Corpoica Cienc. Tecnol. Agropecu. 2014, 15, 83-99. (In Spanish)

8. ISSS/ISRIC/FAO. World reference base for soil resources. In World Soil Resources Reports; FAO: Rome, Italy, 1998; Volume 84.

9. Soil Survey Staff. Keys to Soil Taxonomy, 8th ed.; USDA-NRCS: Washington, DC, USA, 1998.

10. Olsen, S.R.; Sommers, L.E. Phosphorus. In Methods of Soil Analysis. Part2. Chemical and Microbiological Properties, Agronomy Monograph 9.2; Miller, R.H., Keeney, E.R., Eds.; America Society Agronmy, Inc. and Soil Science of America, Inc.: Madison, WI, USA, 1982; pp. 1035-1049.

11. Palacios-Díaz, M.P.; Mendoza-Grimón, V.; Fernández-Vera, J.R.; Hernández-Moreno, J.M. Effects of defoliation and nitrogen uptake on forage nutritive values of Pennisetum sp. J. Anim. Plant Sci. 2013, 23, 566-574.

12. Tropical Forages: An Interactive Selection Tool. Available online: http://www.tropicalforages.info/ (accessed on 21 May 2015).

13. Zhang, H.; Oweis, T. Water-yield relations and optimal irrigation scheduling of wheat in the Mediterranean region. Agric. Water Manag. 1999, 38, 195-211.

(C) 2015 by the authors; licensee MDPI, Basel, Switzerland. This article is an open access article distributed under the terms and conditions of the Creative Commons Attribution license (http://creativecommons.org/licenses/by/4.0/). 